\title{
Fructan degradation and hydrolytic activity in tuberous roots of Viguiera discolor Baker (Asteraceae), a herbaceous species from the cerrado
}

\author{
MARIA I. DEGASPERI ${ }^{1}$, NAIR M. ITAYA ${ }^{1}$, MARCOS S. BUCKERIDGE ${ }^{1}$ \\ and RITA DE CÁSSIA L. FIGUEIREDO-RIBEIRO ${ }^{1,2}$
}

(received: August 1, 2001; accepted: August 28, 2002)

\begin{abstract}
Fructan degradation and hydrolytic activity in tuberous roots of Viguiera discolor Baker (Asteraceae), a herbaceous species from the cerrado). Fructans of the inulin type are the major reserve carbohydrates in tuberous roots of Viguiera discolor, a perennial herb native to the cerrado. Changes in molecular mass of the polymer, followed by releasing free fructose suggested that hydrolysis could be related to the sprouting of the buds after the dormant period, when aerial parts of the plant are naturally absent. Excision of aerial parts resulted in the increase of fructan 1-exohydrolase (1-FEH) activity in tuberous roots after sprouting. 1-FEH was partially purified from this material by binding to ConA-Sepharose and the highest activity was detected at $\mathrm{pH} 5.4$ and between 20 and $40{ }^{\circ} \mathrm{C}$. Values of $\mathrm{K}_{\mathrm{m}}$ for $V$. discolor inulin could not be determined since no saturation was observed up to $10 \%$. The study of the kinetics of the 1-FEH activity showed that it does not follow MichaelisMenten and apparently presents allosteric behaviour, as data fits in the Hill equation. The 1-FEH from $V$. discolor is a glycoprotein, more active on low molecular mass fructans than on high molecular mass inulin from the same species.
\end{abstract}

Key words - Asteraceae, cerrado, fructan 1-exohydrolase, inulin

RESUMO - (Degradação de frutanos e atividade hidrolítica em raízes tuberosas de Viguiera discolor Baker, uma espécie herbácea de Asteraceae do cerrado). Frutano do tipo inulina é o principal carboidrato de reserva das raízes tuberosas de Viguiera discolor, uma espécie herbácea nativa do cerrado. Variações na massa molecular do polímero, acompanhadas de altas proporções de frutose livre sugeriram que a hidrólise do mesmo poderia estar associada à brotação das plantas, após o período de dormência, quando toda a parte aérea é naturalmente eliminada. Após indução experimental de brotação e estímulo da atividade hidrolítica, por eliminação da parte aérea, o extrato enzimático foi parcialmente purificado por adsorção em Sepharose ConA, sendo a maior atividade detectada em pH 5,4 e entre 20 e $40{ }^{\circ} \mathrm{C}$. Não foi possível determinar os valores de $\mathrm{K}_{\mathrm{m}}$ para a inulina, uma vez que até a concentração de $10 \%$ não houve a saturação do substrato. O estudo da cinética da atividade de frutano 1- exohidrolase mostrou que a mesma não corresponde à cinética de Michaelis-Menten, apresentando um comportamento aparentemente alostérico, uma vez que os dados se enquadram na equação de Hill. A 1-FEH de $V$. discolor é uma glicoproteína, mais ativa sobre oligofrutanos do que sobre inulina de alta massa molecular, como a encontrada em outras Asteráceas, e principalmente na própria espécie.

Palavras-chave - Asteraceae, cerrado, frutano 1-hexohidrolase, inulina

\section{Introduction}

Fructans are the main reserve carbohydrates in Asteraceae and in many other economically important families, such as Poaceae and Liliaceae (Pollock 1986). Fructans are synthesised by the combined action of sucrose:sucrose 1-fructosyl transferase (1-SST), and fructan:fructan 1-fructosyl tranferase (1-FFT), the main enzyme responsible for the chain elongation (Edelman \& Jefford 1968, Koops \& Jonker 1996, Lüscher et al. 1996, Van den Ende \& Van Laere 1996). This last enzyme, together with fructan 1-exohydrolase (1-FEH), are believed to catalyse fructan depolymerisation at the end of the growing season and during storage and forcing

\footnotetext{
1. Instituto de Botânica, Seção de Fisiologia e Bioquímica de Plantas, Caixa Postal 4005, 01061-970 São Paulo, SP, Brasil.

2._Corresponding author: ritarib@usp.br
}

of tubers and tuberous roots of several species of Asteraceae (De Roover et al. 1999a and ref. therein).

Underground reserve organs presenting high amounts of fructans were found to be present in many species of Asteraceae from the Brazilian cerrado (Figueiredo-Ribeiro et al. 1986, Tertuliano \& Figueiredo-Ribeiro 1993), including Viguiera discolor Baker, that accumulates up to $80 \%$ of the tuberous roots dry mass as fructans of the inulin type. The mean molecular mass of the polymer can reach $28 \mathrm{kDa}$ at the end of the growing period, being five-fold higher than inulin generally found in other Asteraceae species (Isejima et al. 1991). Although the proportions of oligoand polyfructans in the tuberous roots of $V$. discolor changed during periods of re-growth and flowering, the total content of fructans in the underground organs remained relatively high and constant, suggesting that the activity of 1-FEH might be inhibited in those organs 
throughout the phenological cycle of the plants (Isejima \& Figueiredo-Ribeiro 1993).

In yacon (Polymnia sonchifolia Poep \& Endl.), an Asteraceae native to the Andes, the underground organs accumulate mainly low degree of polymerization (DP) fructans of the inulin type (Goto et al. 1995) and the 1-FEH activity was found to be high and relatively constant throughout the growth cycle (Itaya et al. 2001), increasing drastically when the aerial parts were cut or naturally damaged (Fukai et al. 1997). These facts suggest that 1-FEH might be activated by the reduction of the photoassimilates supply and/or in periods of increased demand for energy. More recently Van den Ende et al. (2001) considered the 1-FEH II purified from tuberous roots of Cichorium intybus L. (De Roover et al. 1999b) as a "survival" enzyme due to the fact that it was strongly induced in the roots mainly after defoliation, when energy demands greatly increased.

Despite the importance of determining the properties of the enzymes involved in fructan depolymerisation for the understanding of fructan breakdown, only a few 1-FEHs from dicots have been purified to electrophoretic homogeneity (Claessens et al.1990, Marx et al. 1997, De Roover et al. 1999b, Henson 2000).

Inulin is widely recognised as a health-improving product, being utilised as dietary fibre, low-caloric sweetener and fat replacer (Carvalho \& FigueiredoRibeiro 2001 and ref. therein). Considering the large amounts of inulin found in the tuberous roots of Viguiera discolor and the increasing interest for commercial production and industrial application of this polymer, the present work aimed at analysing 1-FEH activity in those roots, in order to understand its role in fructan catabolism in the context of the cerrado ecophysiology. The work also contributes to future exploitation and utilisation of natural resources from the cerrado.

\section{Material and methods}

Plant material - Tuberous roots of Viguiera discolor Baker (Asteraceae) were harvested from plants cultivated in the Institute of Botany of São Paulo, Brazil, originally produced from seeds collected from plants growing naturally in a preserved area of cerrado near Moji-Guaçu, $\mathrm{SP}$, Brazil $\left(22^{\circ} 15-8^{\prime} \mathrm{S}\right.$ and $\left.47^{\circ} 8-12^{\prime} \mathrm{W}\right)$. Tuberous roots with different sizes (0.1-1.5 cm diameter) from 17 monthold plants at early dormancy (eighteen plants) were excised, thoroughly washed in running tap water, peeled, cut into small pieces and used for soluble carbohydrate and enzymatic extractions and for determination of dry matter by freeze-drying until constant mass.

Induction of 1-FEH activity - Aiming to increase the 1-FEH activity, as performed for other Asteraceae species (De Roover et al. 1999a), tuberous roots smaller than $0.5 \mathrm{~cm}$ diameter and the aerial organs were removed from plants of $V$. discolor previously cultivated in a greenhouse during two years in individual pots ( 2 L capacity) containing soil. To enhance further the induction of FEH activity, the plants were kept without water for ten days and the larger tuberous roots were harvested. This coincided with the regrowth of the aerial parts. The shoots of control plants were not excised and the irrigation was maintained regularly throughout the experimental period.

Preparation of the enzyme extract - The tuberous roots were washed, peeled and cut into pieces. The proteins were extracted in a chilled mortar and pestle with McIlvaine buffer $\mathrm{pH} 5.4$, containing $2 \mathrm{mM} \beta$-mercapto-ethanol and $0.02 \%$ sodium azide. The tissues were ground together with two freshly broken Pasteur pipettes to form a smooth paste, as described by Cairns (1992). The slurry was filtered through two layers of nylon and then centrifuged for $30 \mathrm{~min}$ at $30,000 \mathrm{~g}$. The supernatant was dialysed for $24 \mathrm{~h}$ against $2 \mathrm{~L}$ of buffer (diluted five-fold), with eight changes. The dialysed suspension was centrifuged at $13,000 \mathrm{~g}$ for $10 \mathrm{~min}$. All procedures were carried out at $5^{\circ} \mathrm{C}$.

Purification of the enzyme extract - Dialysed crude extracts prepared from tuberous roots of larger sizes (higher than $0.5 \mathrm{~cm}$ diameter) were loaded at a flow rate of $0.3 \mathrm{~cm}^{3} \cdot \mathrm{min}^{-1}$ on to Concanavalin-A (Con A) Sepharose column (Pharmacia, $15 \mathrm{~mm}$ diameter $\times 60 \mathrm{~mm}$ height) in $50 \mathrm{mM}$ phosphate-citrate buffer ( $\mathrm{pH} 5.5$ ) containing $1 \mathrm{mM} \mathrm{CaCl}$ and $1 \mathrm{mM} \mathrm{MnCl}$. Proteins bound to the column were eluted with $40 \mathrm{mM} \alpha$-D-methyl- mannopyranoside dissolved in the same buffer.

Extraction and analysis of soluble carbohydrates from tuberous roots - Freeze dried powder $(0.25 \mathrm{~g})$ of tuberous roots was boiled with $2.5 \mathrm{~mL} \mathrm{80 \%} \mathrm{v/v} \mathrm{ethanol} \mathrm{and} \mathrm{processed}$ for soluble carbohydrate extraction according to the method described by Pollock \& Jones (1979). Fructooligosaccharides extracted with $80 \%$ ethanol were analysed separately from the inulin, which was extracted twice with distilled water at $60{ }^{\circ} \mathrm{C}$, for $30 \mathrm{~min}$.

After de-ionisation through Dowex resins (cationic and anionic forms), the neutral carbohydrates were analysed by high performance anion exchange chromatography with pulsed amperometric detection (HPAEC/PAD) using a $4 \times 250 \mathrm{~mm}$ CarboPac PA-1 column on a Dionex System Mod. DX 300 (USA), according to Itaya et al. (1999). Sugars were identified by cochromatography with authentic standards. Purified samples of nystose and 1-kestose were used for comparison. The apparent DP of the oligomers was determined against the chromatographic mobilities of fructans extracted from dormant tubers of Helianthus tuberosus L. Alternatively, the products of enzyme 
reactions were analysed on a CarboPac PA-100 column using a linear gradient of $25 \mathrm{mM}$ to $500 \mathrm{mM}$ sodium acetate in $150 \mathrm{mM}$ sodium hydroxide at a flow rate of $1 \mathrm{~mL} \cdot \mathrm{min}^{-1}$ (Shiomi 1993). Free and combined fructose were measured by a ketose-specific modification of the anthrone reaction (Jermyn 1956), using inulin from H. tuberosus as standard.

Fructo-oligosaccharides were also analysed by ascending thin-layer chromatography (TLC), running twice in a solvent system consisting of butan-1-ol, propan-2-ol and water (3:12:4, v/v) according to Kanaya et al. (1978). Oligosaccharide standards of inulin series were prepared from tubers of $H$. tuberosus as described by Cairns \& Pollock (1988). Ketoses were detected with urea-phosphoric acid reagent (Wise et al. 1955).

Measurement of enzyme activities - Samples of enzyme preparations $(100 \mu \mathrm{L})$ were mixed with an equal volume of citrate phosphate (McIlvaine) buffer $\mathrm{pH} 5.4$ containing $600 \mathrm{mM}$ 1-kestose, $400 \mathrm{mM}$ nystose or $10 \%(\mathrm{w} / \mathrm{v})$ inulin purified from tuberous roots of $V$. discolor at vegetative phase (Isejima \& Figueiredo-Ribeiro 1993). The mixtures were incubated at $30^{\circ} \mathrm{C}$ for $6 \mathrm{~h}$. The reactions were stopped by injecting $2 \mu \mathrm{L}$ of the assay mixture diluted in $500 \mu \mathrm{L}$ of de-ionised water directly into the HPAEC/PAD system. Alternatively, samples were centrifuged at $13.000 \mathrm{~g}$ for $10 \mathrm{~min}$ and their supernatants were stored at $-20{ }^{\circ} \mathrm{C}$ prior to quantitative analysis of sugars by HPAEC/PAD or by the Somogyi-Nelson's reagent (Somogyi 1945) using free fructose (Sigma) as standard.

The effect of $\mathrm{pH}$ was determined using Mcllvaine buffer in the $\mathrm{pH}$ range of 4.6 to 6.2 and the optimal assay temperature was determined between $5{ }^{\circ} \mathrm{C}$ and $60^{\circ} \mathrm{C}$. To determine kinetic parameters for 1-FEH, enzyme preparations were incubated for $6 \mathrm{~h}$ at $30^{\circ} \mathrm{C}$, pH 5.4, with seven inulin concentrations between 0.25 and $10 \%(\mathrm{w} / \mathrm{v})$. The Hill constant was determined after incubation with $0.5,1,2,5$ and $8 \%$ inulin from $V$. discolor for $1,2,4$ and $6 \mathrm{~h}$, for each substrate concentration.

The activities of 1-FEH on different substrates were determined using sucrose, 1-kestose, nystose, inulin from Helianthus tuberosus, Vernonia herbacea Rusby (prepared as already described by Carvalho \& Dietrich 1993) and Viguiera discolor, levan from Aerobacter levanicum (Sigma) and phlein from Gomphrena macrocephala A. St.-Hil. (Shiomi et al. 1996).

Protein concentrations in enzyme preparations were determined by the BioRad protein assay, which is essentially based on the Bradford procedure (1976). Bovine serum albumin was used as standard.

\section{Results and Discussion}

The average degree of polymerisation (DP) of fructans stored by tuberous roots of Viguiera discolor is predominantly high (130 to 174 fructose residues) depending on the phenological phase (Isejima \& Figueiredo-Ribeiro 1993).

Analysis of fructans from tuberous roots of different sizes (figure 1A), collected from plants at early dormancy, revealed that an inulin-like fructan series is already present at the beginning of tuberisation process (i.e. in tuberous roots of increasing sizes - figure 1B). As shown in this figure, the distribution pattern of the fructooligosaccharides is similar along different root sizes, except for the bigger ones (1.5 cm diameter), which presented higher proportions of the pentasaccharide and fructans higher than DP 9. In roots of all sizes, the low molecular mass sugars occur in higher proportions, being composed mainly of fructose, sucrose, 1-kestose and nystose (figure 1B). Our results confirm the ones obtained by Isejima \& Figueiredo-Ribeiro (1993) who found that fructans of intermediate sizes from DP 5 to

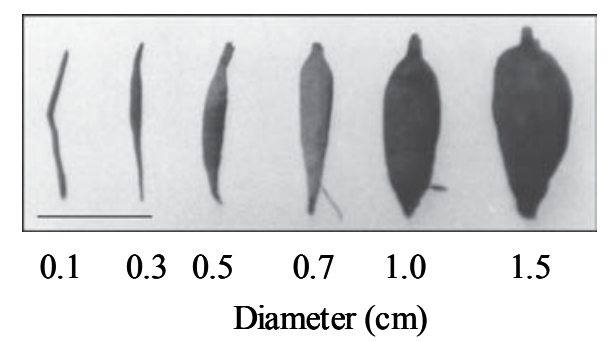

A

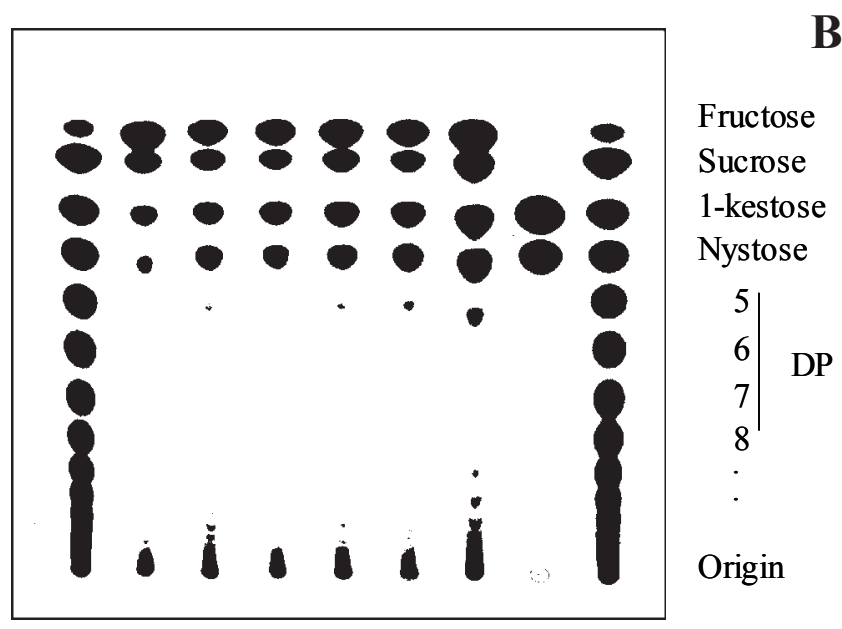

$\begin{array}{lllllll}\mathrm{Ht} & 0.1 & 0.3 & 0.5 & 0.7 & 1.0 & 1.5 \mathrm{~N}+1 \mathrm{k} \mathrm{Ht}\end{array}$

Figure 1. (A) Tuberous roots with different sizes ( 0.1 to $1.5 \mathrm{~cm}$ diameter $-\mathrm{Bar}=2 \mathrm{~cm}$ ) collected from 18 month-old plants of Viguiera discolor at early dormancy and (B) thin layer chromatography of fructo-oligosaccharides. Each lane contains approximately $50 \mu \mathrm{g}$ of fructose equivalents. $\mathrm{Ht}=$ fructo-oligosaccharides from tubers of Helianthus tuberosus used as reference; $\mathrm{N}=$ nystose; $1 \mathrm{~K}=1$-kestose; $\mathrm{DP}=$ degree of polymerisation. 
9 were absent or in very low concentrations in the tuberous roots of $V$. discolor.

Fractionation between ethanol and hot water soluble fructans showed that the high molecular mass fructans

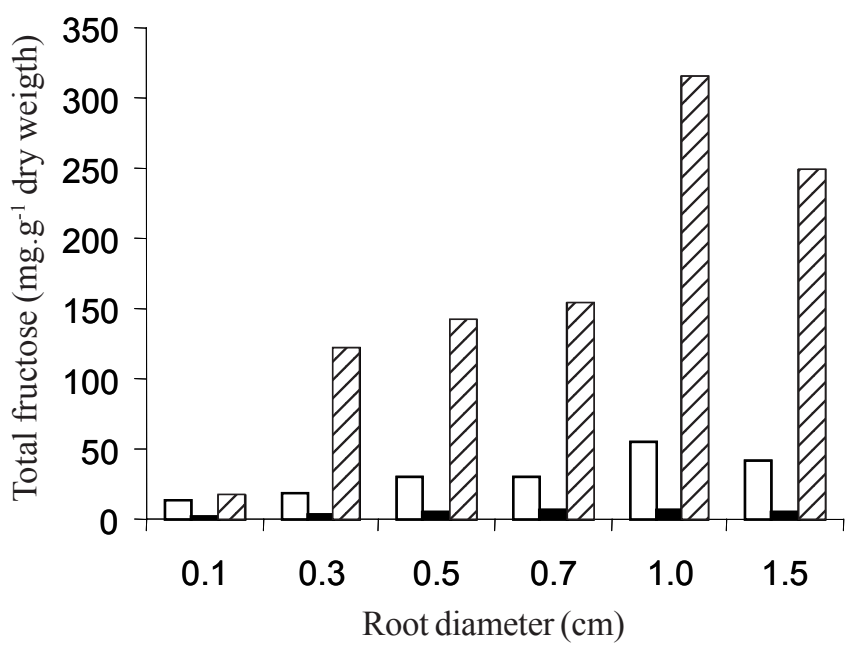

Figure 2. Free and combined fructose contents (mg.g ${ }^{-1}$ dry mass) in different fractions (oligofructans $=\square$; fructans of intermediate size $=\square$; polyfructans $=\square$ extracted with $80 \%$ ethanol and hot water from tuberous roots of $V$. discolor with different sizes.

were present in larger amounts mainly in the bigger roots, especially those of $1.0 \mathrm{~cm}$ diameter (figure 2).

Figure 3 shows fructan hydrolase activity in tuberous roots of different sizes (see also figure 1A), measured as the release of free fructose using 1kestose and high DP fructans from $V$. discolor. When crude enzyme extracts were incubated with 1-kestose (figure 3A) relatively higher proportions of fructose were produced, mainly in the small roots, at the beginning of the tuberisation process. This result suggests the presence of an 1-FEH more active on low DP fructans. Previously, Isejima \& Figueiredo-Ribeiro (1993) speculated that fructo-oligosaccharides might also be substrates for fructan hydrolases. They suggested that on the basis of the fact that intermediate (DP 5-9) fructan oligosaccharides were not detectable in any stage of development of $V$. discolor, except for dormant plants. Figure $3 \mathrm{~A}$ also shows that in tuberous roots with a diameter higher than $0.5 \mathrm{~cm}$, nystose was the main product from the incubation with 1-kestose, indicating the predominance of 1 -FFT activity throughout the tuberisation process.

Itaya et al. (1997) demonstrated that crude enzyme extracts prepared from tuberous roots of $V$. discolor at dormancy phase were able to produce high DP fructans in vitro when incubated with nystose. These authors also observed the presence of free fructose in low amounts, but it was not possible to demonstrate a clear association with any hydrolase (invertase or fructan hydrolase) of the system. However, the possibility of a 1-FFT side activity, transfering fructose to water in the smaller roots could not be discarded (Van den Ende et al. 1996).

Figure 3B shows the hydrolytic activity in tuberous roots of different sizes on high molecular mass inulin from $V$. discolor. As shown in this figure, 1-FEH activity was practically absent in the smaller roots, increasing markedly with root size, the $1.5 \mathrm{~cm}$ diameter root having 150 fold more activity than the smaller ones $(0.1 \mathrm{~cm})$.
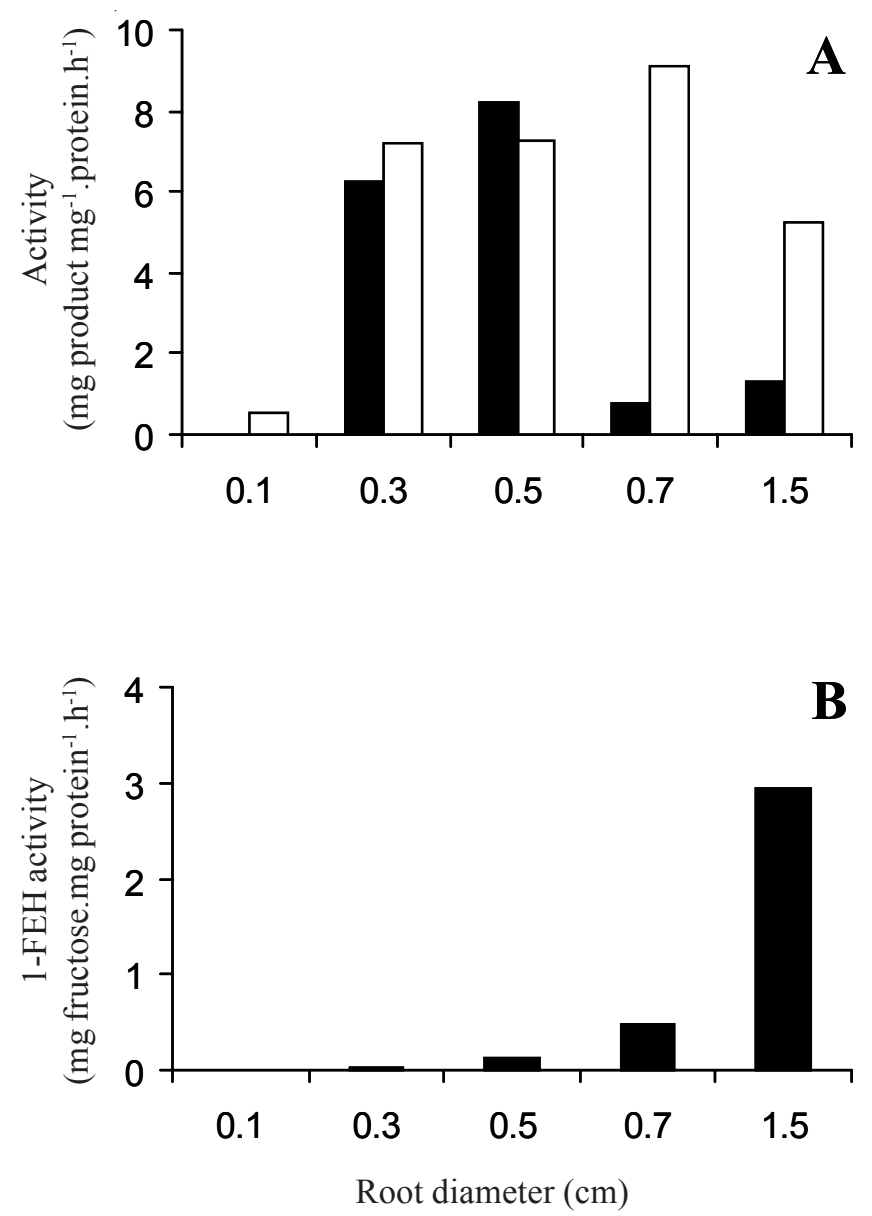

Figure 3. Fructan 1-exo-hydrolase activity (1-FEH) of crude extracts from tuberous roots of $V$. discolor with different sizes on 1-kestose (A) and on inulin purified from the same plant (B). 1-FEH activity is expressed as mg of fructose produced in $60 \mathrm{~min}$ per $\mathrm{mg}$ of protein. Fructose $(\square)$ and nystose $(\square)$ concentrations were calculated from the reaction products analysed by HPAEC/PAD on CarboPac PA-1 column. 
Comparing the hydrolytic activity on high DP inulin found in tuberous roots of $V$. discolor with the ones reported for other species of Asteraceae that store fructan (Claessens et al. 1990, Marx et al. 1997) it is noticeable that hydrolase activity in $V$. discolor is comparatively low.

It has been demonstrated that natural or artificial loss of aerial parts induces fructan exo-hydrolase activity in underground organs (Fukai et al. 1997, De Roover et al. 1999a). In the present work, excision of the shoots in plants of $V$. discolor increased fructan hydrolase activity when nystose ( 1.5 fold) and mainly when high molecular mass inulin (170 fold) were used as substrates (data not shown). HPAEC/PAD analyses confirmed these results, showing that free fructose is produced from the incubation of high DP inulin of $V$. discolor and nystose with crude extracts prepared from the larger roots, mainly in those harvested from plants after defoliation (figures 4D, 5D). One unresolved peak, which was eluted near the retention time of 1 -kestose, was also detected (figure 4D) under the chromatographic conditions used, being possibly a side product (inulobiose?) of the contaminant 1-FFT activity.
On the basis of these results, further experiments designed to characterise the hydrolytic activity were performed using tuberous roots of larger sizes harvested from plants induced for fructan breakdown by excision of aerial parts.

Affinity chromatography on Sepharose Con-A retained enzyme activity (figure 6) showing that FEH is a glycoprotein as found for the same enzyme extracted from different plants including species from Poaceae and Asteraceae families (Bonnett et al. 1994, De Roover et al. 1999b). Elution of the activity was obtained with $40 \mathrm{mM}$ methyl- $\alpha-\mathrm{D}$-mannopyranoside, the maximal activity (peak) obtained being of $0.924 \mu$ moles of fructose $\mathrm{mL}^{-1} \cdot \mathrm{h}^{-1}$. Although the factor of purification was low (approx. two times), analysis by SDS-PAGE of the active fraction revealed one main band with approximately $60 \mathrm{kDa}$ (data not shown).

Using the semi-purified fraction from the Sepharose Con-A, it was demonstrated that activity was linear with time up to $16 \mathrm{~h}$ under the conditions used (figure 7A); the $\mathrm{pH}$ optimum was 5.4 (figure 7B) and the optimal temperature was in the range between 20 and $40{ }^{\circ} \mathrm{C}$ (figure $7 \mathrm{C}$ ). These optimal conditions are similar to

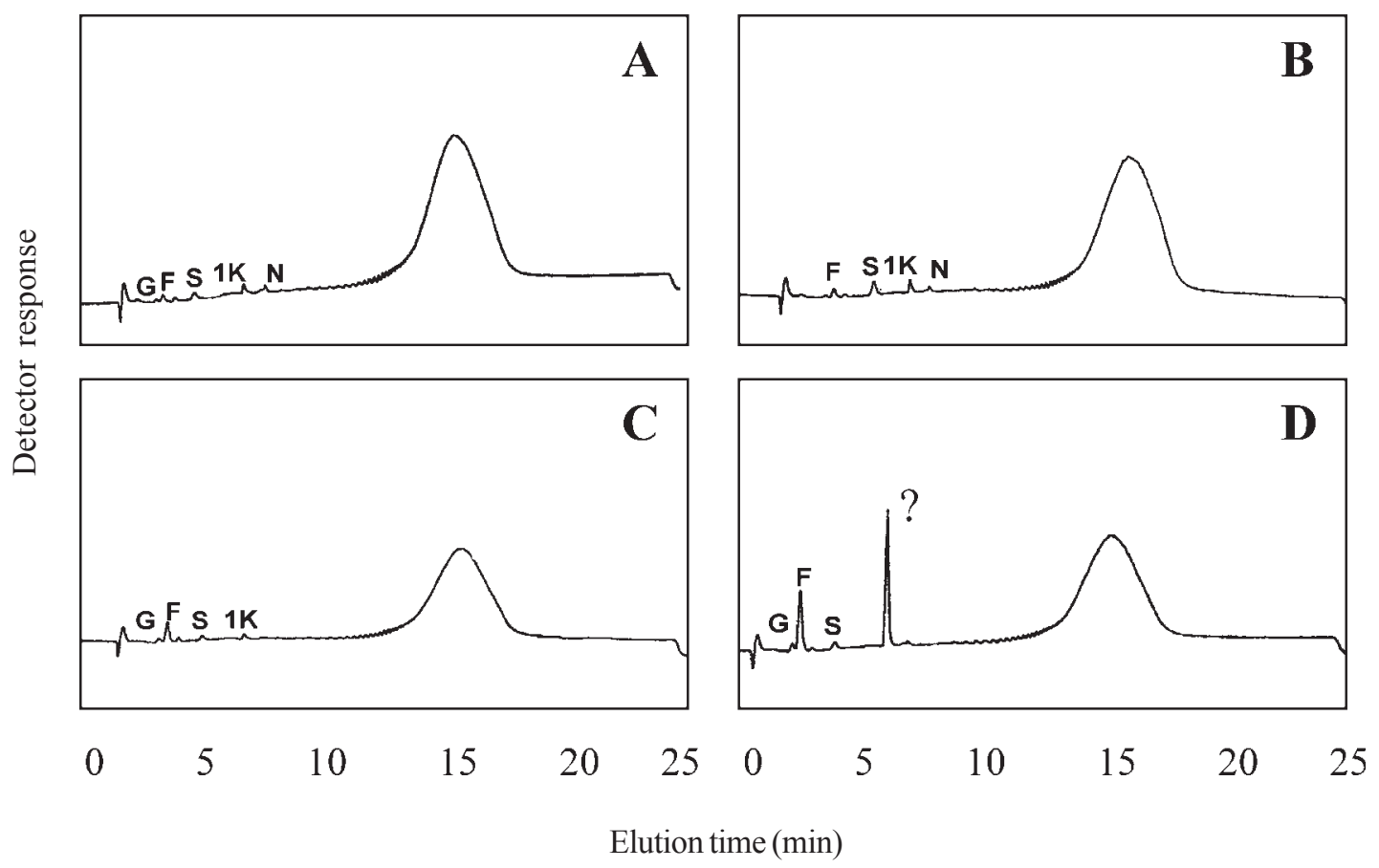

Figure 4. HPAEC/PAD analysis of the reaction products after $5 \mathrm{~h}$ incubation $(\mathrm{B}, \mathrm{D})$ at $30^{\circ} \mathrm{C}$ of crude enzyme extracts from tuberous roots $(0.5$ to $1.0 \mathrm{~cm}$ diameter) of $\mathrm{V}$. discolor with $10 \%(\mathrm{w} / \mathrm{v})$ inulin purified from the same plant. A and $\mathrm{B}=$ noninduced; $\mathrm{C}$ and $\mathrm{D}=$ induced plants, $\mathrm{A}$ and $\mathrm{C}=$ time zero. Markers $\mathrm{G}, \mathrm{F}, \mathrm{S}, 1-\mathrm{K}$ and $\mathrm{N}$ refer to retention times of authentic standards of glucose, fructose, sucrose, 1-kestose and nystose respectively. I = inulin from tuberous roots of $V$. discolor used as substrate. 


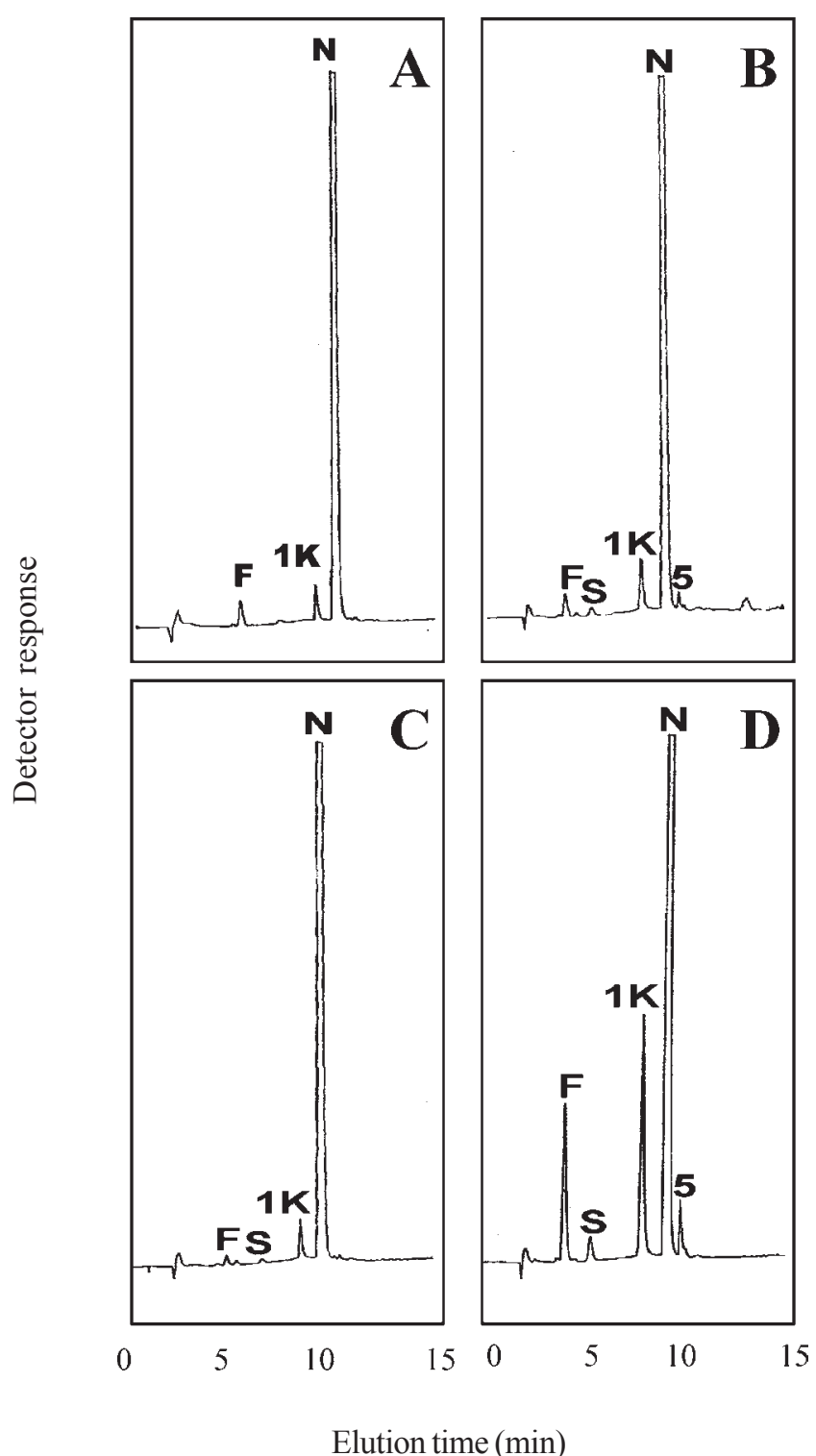

Figure 5. HPAEC/PAD analysis of the reaction products after $5 \mathrm{~h}$ incubation (B,D) at $30^{\circ} \mathrm{C}$ of crude enzyme extracts from tuberous roots $(0.5-1.0 \mathrm{~cm}$ diameter) of $V$. discolor with $200 \mathrm{mM}$ nystose. $\mathrm{A}$ and $\mathrm{B}=$ non-induced; $\mathrm{C}$ and $\mathrm{D}=$ induced plants, $\mathrm{A}$ and $\mathrm{C}=$ time zero. Markers $\mathrm{G}, \mathrm{F}, \mathrm{S}, 1-\mathrm{K}$ and $\mathrm{N}$ refer to retention times of authentic standards of glucose, fructose, sucrose, 1-kestose and nystose respectively. $5=$ pentasaccharide of the inulin series.

those found for similar FEH activities in mono and dicots (Yamamoto \& Mino 1985, Henson \& Livingston 1996, Marx et al. 1997, Henson 2000).

The substrate saturation curve of the semi-purified 1FEH (figure 8A) presented a sigmoid shape as opposed to the hyperbolic shape of Michaelis-Menten kinetics. In order to check the authenticity of the results, a study of the time courses of enzyme activity at the lower inulin concentrations was performed (figure 8B). The observation that the time courses of activity are linear with time (from zero to $6 \mathrm{~h}$ ), even at low concentrations of inulin, demonstrated that the lower activity found at lower concentrations (figure 8A) was not due to availability of substrate. These results suggested that the 1-FEH activity from $V$. discolor might behave as an allosteric enzyme. Although this kinetic behaviour is uncommon for glycosidases, at least for Cichorium intybus (Gupta et al. 1993) the inulinase activity related with parenchyma and vascular bundles was found to behave in a sigmoidal fashion. In this case, the substrate used was inulin extracted from chicory roots.

Assuming that the 1-FEH from $V$. discolor behaves allosterically, one experiment was conducted to estimate the Hill constant, so that the cooperativism of the reaction could be assessed. The results (figure $8 \mathrm{C}$ ) showed a Hill constant of 2.11, indicating that two active sites would be involved in the reaction with high positive cooperativism (Segel 1979).

Figure 9 shows the products of the action of semipurified 1-FEH activity on nystose (figures 9A, 9B) and on inulin from $V$. discolor (figures 9C, 9D). Although free fructose was produced by the action on both substrates, the hydrolysis of nystose also produced sucrose and 1-kestose. The detection of low amounts of the pentasaccharide of the inulin series suggests a contamination with 1-FFT activity. On the other hand, the attack of 1-FEH to inulin of high molecular mass

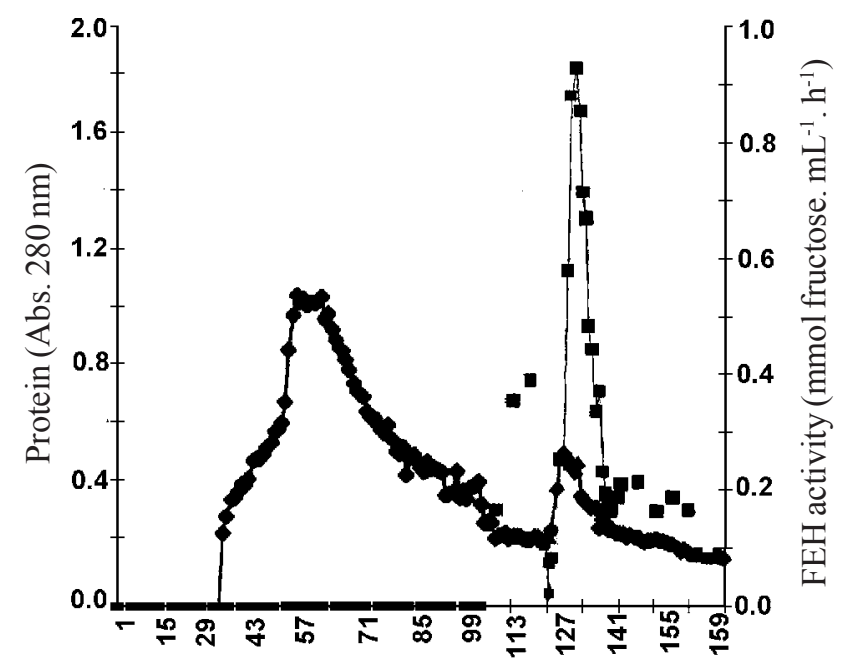

Fraction number

Figure 6. Elution profile on concanavalin A (ConASepharose) affinity chromatography of enzymatic extracts from induced tuberous roots of $V$. discolor. $\boldsymbol{\nabla}=$ protein; $\mathbf{\square}=$ $1-\mathrm{FEH}$ activity. Fraction volume $=1.5 \mathrm{~mL}$. 
produced only free fructose, therefore characterising the hydrolytic activity (figure 9D).

Other fructose containing compounds were used as substrates for 1-FEH activity (table 1) and our results show that the glycosidic linkage attacked is the $\beta-2,1$ as
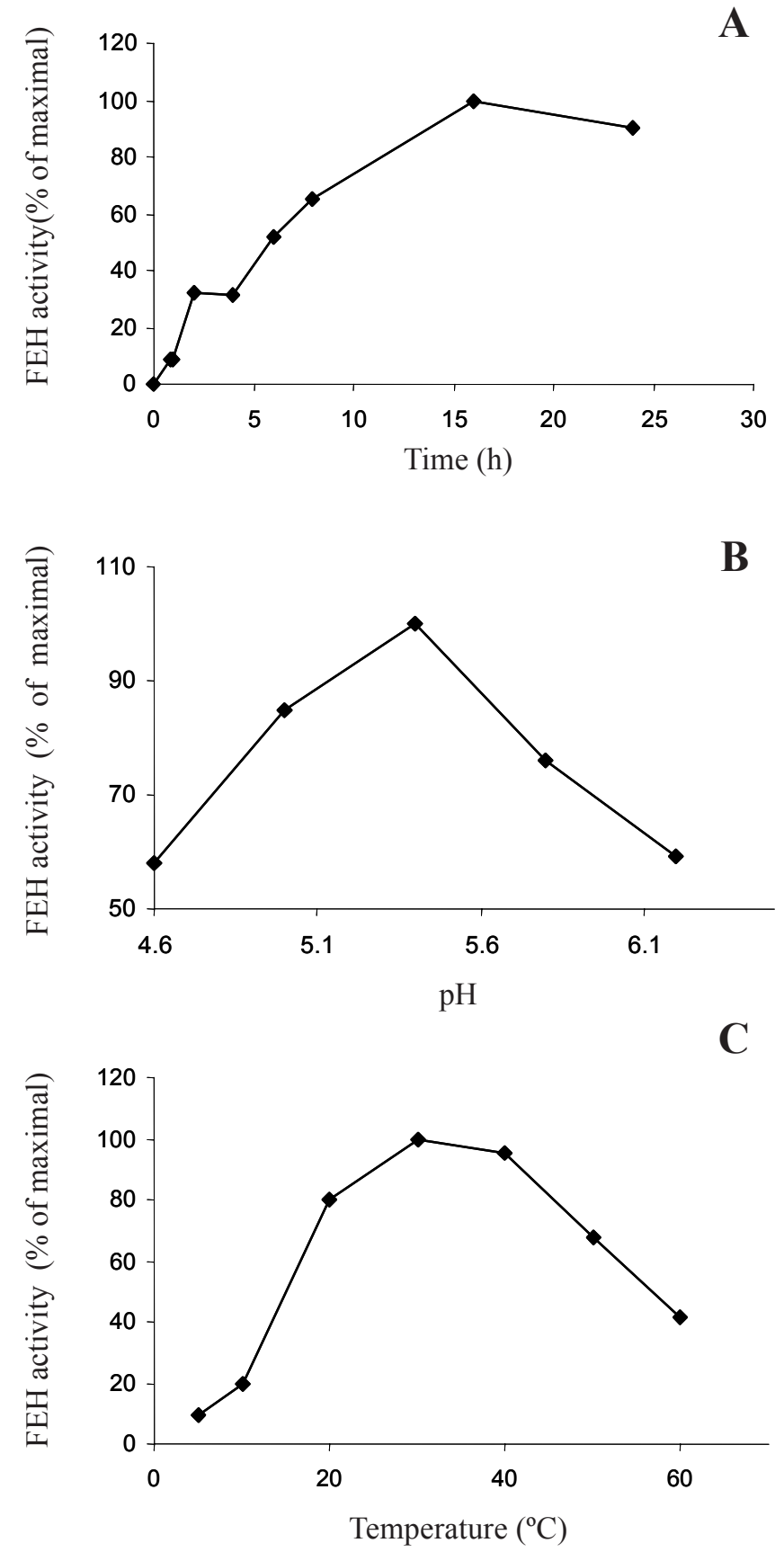

Figure 7. Characterisation of 1-FEH activity from tuberous roots of $V$. discolor. A = time course of free fructose production on $5 \%(\mathrm{w} / \mathrm{v})$ purified $V$. discolor inulin in Mcllvaine buffer $\mathrm{pH} 5$ at $30^{\circ} \mathrm{C}$. Effects of $\mathrm{pH}(\mathrm{B})$ and temperature (C) on the 1-FEH activity.
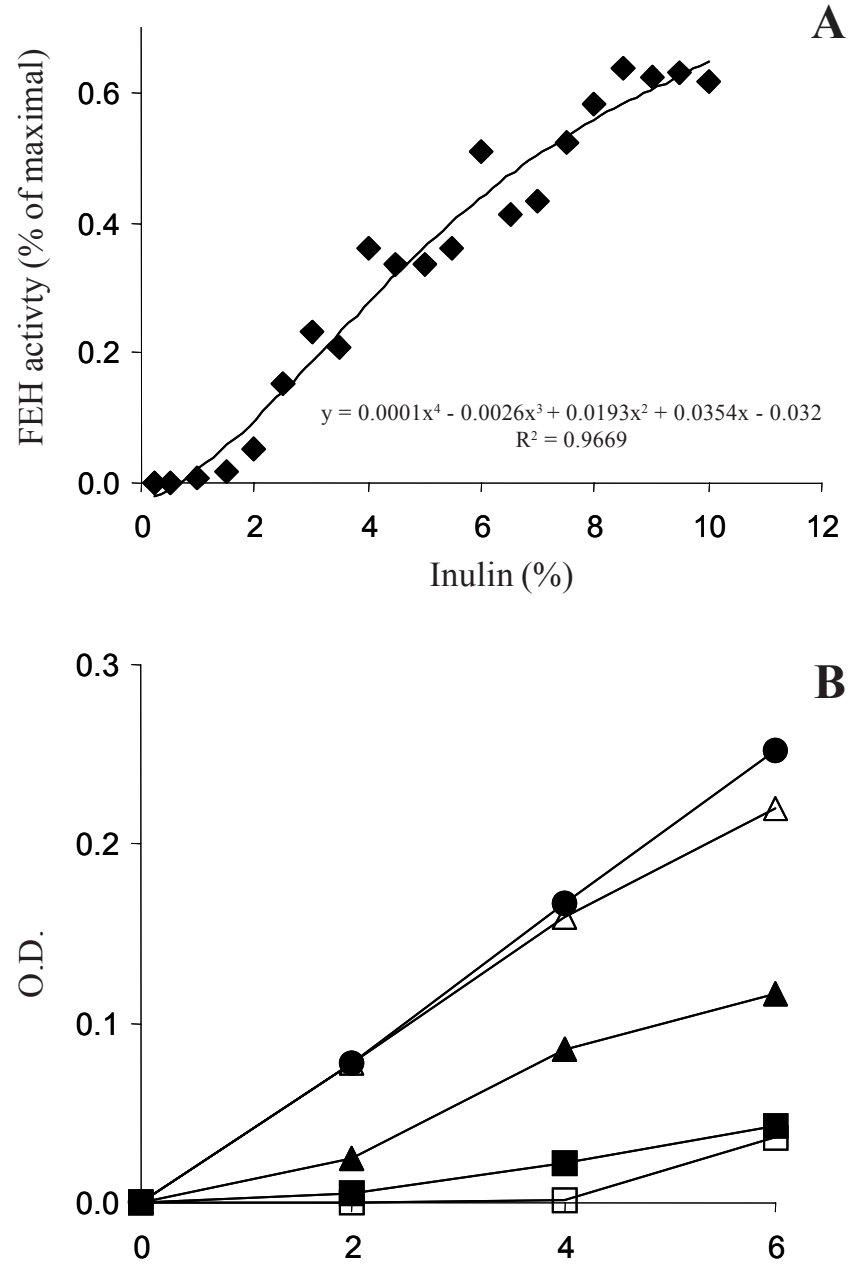

Time (h)

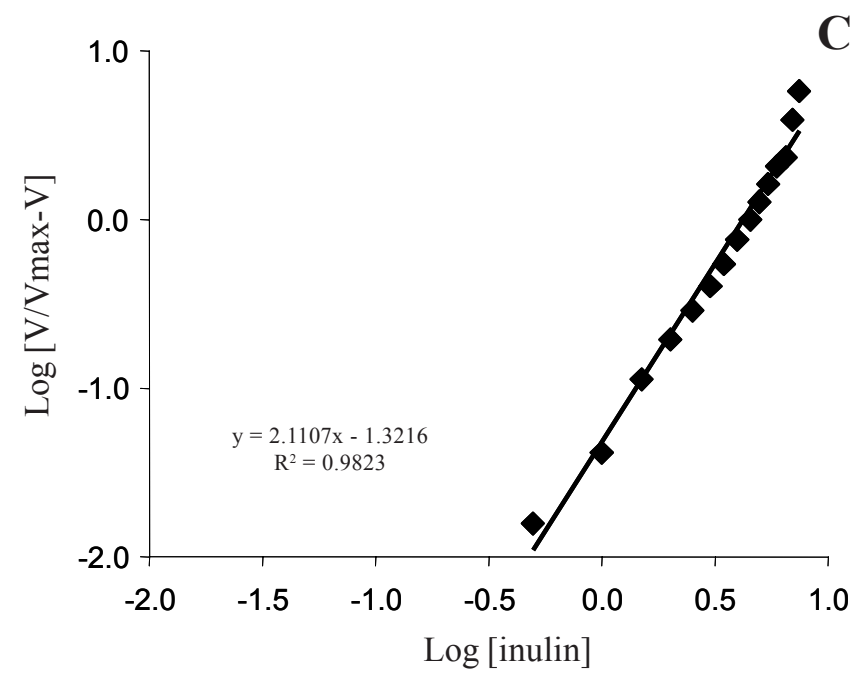

Figure 8. Effect of substrate ( $V$. discolor inulin) concentration on 1-FEH activity (A) and concentration curve $(\square=0.5 \%, \boldsymbol{\square}=1.0 \%, \boldsymbol{\Delta}=2.0 \%, \bullet=6.0 \%$ and $\triangle=8.0 \%$ inulin from $V$. discolor) at $0 \mathrm{~h}, 2 \mathrm{~h}, 4 \mathrm{~h}$ and $6 \mathrm{~h}$ incubation (B). C = "Plot Hill". 

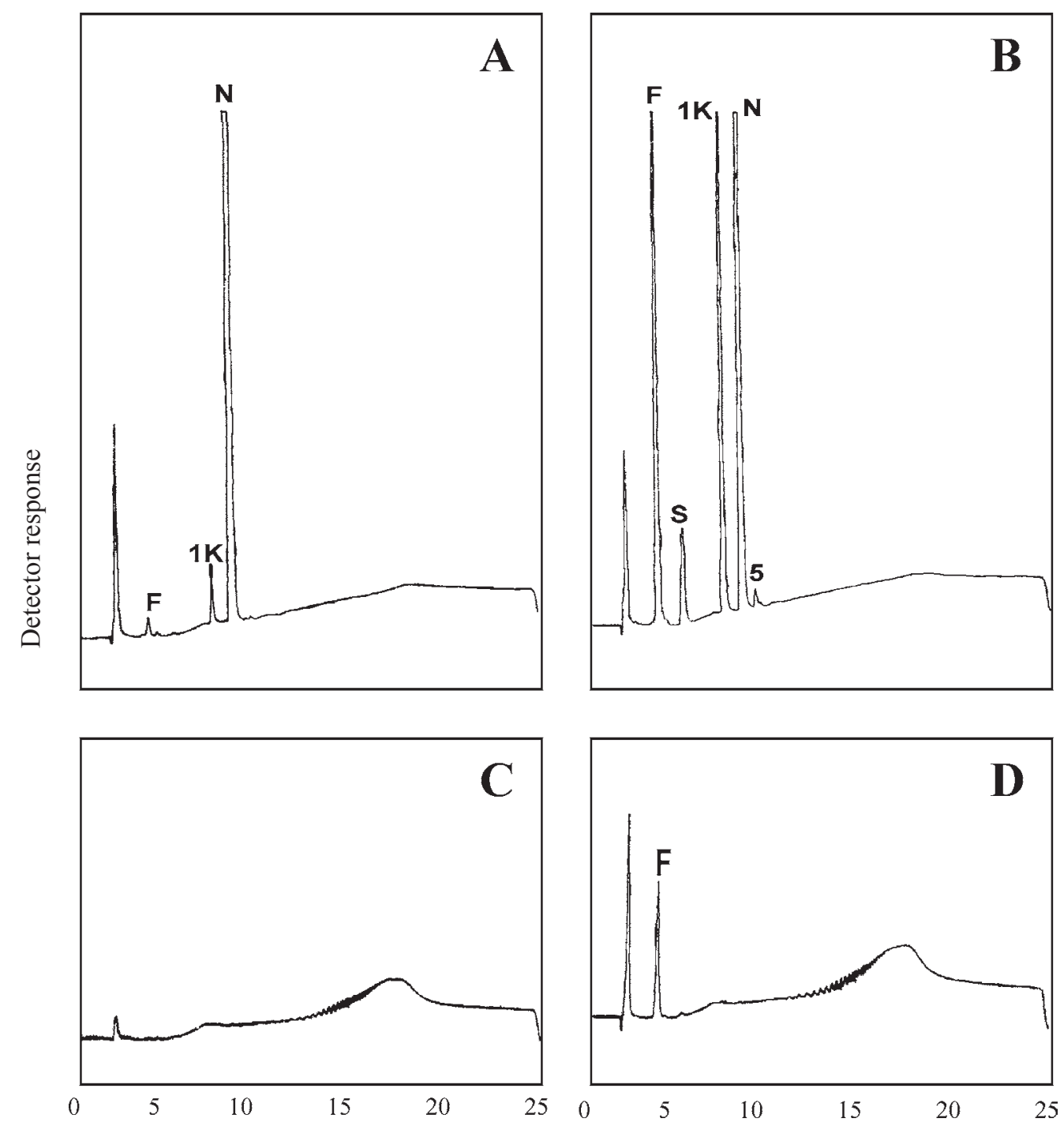

Elution time (min)

Figure 9. HPAEC/PAD analysis of the reaction products after incubation of semi-purified 1-FEH from $V$. discolor with 400 $\mathrm{mM}$ nystose for $0 \mathrm{~h}(\mathrm{~A})$ and $6 \mathrm{~h}(\mathrm{~B})$ and with $10 \%(\mathrm{w} / \mathrm{v})$ inulin from $0 \mathrm{~h}(\mathrm{C})$ and $6 \mathrm{~h}(\mathrm{D}) . \mathrm{F}, \mathrm{S}, 1-\mathrm{K}, \mathrm{N}$ and 5 refer to retention times of authentic standards of fructose, sucrose, 1-kestose, nystose and pentasaccharide of the inulin series, respectively. Assay was performed in Mcllvaine buffer $\mathrm{pH} 5$ at $30^{\circ} \mathrm{C}$.

opposed to $\beta-2,6$, present in tuberous roots of Gomphrena macrocephala (Shiomi et al. 1996).

Further research is needed to understand how fructan hydrolase is regulated throughout the different developmental stages of those roots. Results obtained recently by Van den Ende et al. (2001) showed that 1 -FEH I (that is expressed earlier in the growth cycle) and 1-FEH II, both from Cichorium intybus, are expressed under different conditions and are regulated in a different way. 1-FEH II is strongly induced in roots after defoliation, suggesting that it can be considered as a "survival" enzyme, that is induced at times when energy demands largely increase.

1-FEH and 1-FFT activities from tuberous roots of $V$. discolor co-fractionated during the steps of purification utilised in the present work. Indeed, 1-FFT from other Asteraceae has been shown to be a concanavalin A binding glycoprotein (Van den Ende et al. 1996) and this probably explains why this contamination follows 1-FEH throughout purification. Besides, as shown previously, 1-FFT activity is present during all the annual growth cycle of $V$. discolor (Itaya et al. 1999). 
Table 1. FEH activity from tuberous roots of Viguiera discolor on different fructose-containing substrate (sucrose, 1-kestose, nystose, inulin from Helianthus tuberosus, Vernonia herbacea and Viguiera discolor, levan from Aerobacter levanicum and phlein from Gomphrena macrocephala). Assays were performed for $5 \mathrm{~h}$ at $30^{\circ} \mathrm{C}, \mathrm{pH} 5.0$.

\begin{tabular}{lccr}
\hline Substrate & Concentration & $\begin{array}{c}\text { Total activity } \\
\left.\text { (mg fructose. } \mathrm{mL}^{-1} \cdot \mathrm{h}^{-1}\right)\end{array}$ & $\begin{array}{c}\text { Specific activity } \\
\left(\mathrm{mg} \text { fructose. } \mathrm{mg}^{-1} \mathrm{prot}^{-1} \mathrm{~h}^{-1}\right.\end{array}$ \\
\hline Oligosacchacarides & & & \\
$\quad$ Sucrose & $0.4 \mathrm{M}$ & 0.001 & 0.02 \\
$\quad$ 1-kestose & $0.4 \mathrm{M}$ & 1.20 & 15.00 \\
Nystose & $0.2 \mathrm{M}$ & 1.28 & 15.50 \\
Polysacchacarides & & & 1.56 \\
$\quad$ Viguiera discolor inulin & $10 \%$ & 0.13 & 8.88 \\
$\quad$ Vernonia herbacea inulin & $10 \%$ & 0.73 & 5.42 \\
$\quad$ Helianthus tuberosus inulin & $10 \%$ & 0.42 & 0.00 \\
$\quad$ Gomphrena macrocephala phlein & $10 \%$ & 0.00 & 0.00 \\
Aerobacter levanicum levan & $2 \%$ & 0.00 & \\
\hline
\end{tabular}

The facts that 1-FEH activity is low and increases after excision of the aerial parts of the plant and that 1-FFT predominates among the enzymes that metabolise fructans in $V$. discolor suggest that 1-FFT is a multifunctional enzyme that can also catalyse the hydrolysis of fructans. Then, it can be speculated that the degradation of fructans in the bigger roots of $V$. discolor could be catalysed by the concerted action of 1-FEH and 1-FFT under unfavourable conditions in the cerrado, mainly during the dry winter when the aerial parts are completely eliminated and the energetic demands increase drastically for fast re-growth in the next season. Purification and characterisation of 1-FFT of this plant are in progress and will help strongly to understand fructan catabolism in those roots.

Considering that high hydrolytic activity results in breakdown of fructans during storage of other plants, the low 1-FEH activity found in tuberous roots of $V$. discolor represents an advantage concerning future commercial production and industrial application of high DP inulin. This fact permits to store those roots without manipulation to controlling fructan degradation.

Acknowledgements - The authors thank Dr. Norio Shiomi, from the Rakuno Gakuen University (Japan) for the kind gift of 1kestose and nystose. This work was supported by the State of São Paulo Research Foundation (Fapesp) within the Biota/ Fapesp - The Biodiversity Virtual Institute Program (www.biotasp.org.br). M.I. Degasperi thanks CNPq and N.M. Itaya thanks Fapesp for the fellowships. M.S. Buckeridge and R.C.L. Figueiredo-Ribeiro are fellow researchers of the CNPq.

\section{References}

BONNETT, G.D., SIMS, I.M., ST. JOHN, J.A. \& SIMPSON, R.J. 1994. Purification and characterization of fructans with b-2,1- and b-2,6- glycosidic linkages suitable for enzyme studies. New Phytologist 127:261-269.

BRADFORD, M.M. 1976. A rapid and sensitive method for the quantitation of microgram quantities of protein utilizing the principle of Protein-Dye Binding. Analytical Biochemistry 72:248-254.

CAIRNS, A.J. 1992. Fructan biosynthesis in excised leaves of Lolium temulentum L. V. Enzymatic de novo synthesis of large fructans from sucrose. New Phytologist 122:253-259.

CAIRNS, A.J. \& POLLOCK, C.J. 1988. Fructan biosynthesis in excised leaves of Lolium temulentum L.I. Chromatographic characterization of oligofructan and their labelling patterns following ${ }^{14} \mathrm{CO}_{2}$ feeding. New Phytologist 109:399-405.

CARVALHO, M.A.M. \& DIETRICH, S.M.C. 1993. Variation in fructan contents in the underground organs of Vernonia herbacea (Vell.) Rusby at different phenological phases. New Phytologist 123:735-740.

CARVALHO, M.A.M. \& FIGUEIREDO-RIBEIRO, R.C.L. 2001. Frutanos: Ocorrência, estrutura e utilização, com ênfase em plantas do cerrado brasileiro. In Fibra dietética en Iberoamerica: Tecnologia y Salud. Obtención, caracterización, efecto fisiológico y aplicación en alimentos. Projeto CYTED XI. 6. Obtención y caracterización de fibra dietética para su aplicación en regimenes especiales. (F.M. Lajolo, F. Saura-Calixto, E. Wittig de Penna \& E.W. Menezes, eds.). Varela, São Paulo, p.77-89 
CLAESSENS, G., VAN LAERE, A. \& DE PROFT, M. 1990. Purification and properties of an inulinase from chicory roots (Cichorium intybus L.). Journal of Plant Physiology 136:35-39.

DE ROOVER, J., VANLAERE, A. \& VANDENENDE, W. 1999a. Effect of defoliation on fructan pattern and fructan metabolizing enzymes in young chicory plants (Cichorium intybus). Physiologia Plantarum 106:158-163.

DE ROOVER, J., VAN LAERE, A., DE WINTER, M., TIMMERMANS, J.W. \& VAN DEN ENDE, W. 1999b. Purification and properties of a second fructan exohydrolase from the roots of Cichorium intybus. Physiologia Plantarum 106:28-34.

EDELMAN, J. \& JEFFORD, T.G. 1968. The mechanism of fructosan metabolism in higher plants as exemplified in Helianthus tuberosus. New Phytologist 67:517-531.

FIGUEIREDO-RIBEIRO, R.C.L., DIETRICH, S.M.C.,CHU,E.P., MACHADO DE CARVALHO, M.A., VIEIRA, C.C.J. \& GRAZIANO, T.T. 1986. Reserve carbohydrate in underground organs of native Brazilian plants. Revista Brasileira Botânica 9:159-166.

FUKAI, K., OHNO, S., GOTO, K., NANJO F. \& HARA, Y. 1997. Seasonal fluctuations in fructan content and related enzyme activities in yacon (Polymnia sonchifolia). Soil Science and Plant Nutrition 43:171-177.

GOTO, K., FUKAI, K., HIKIDA, J., NAJO, F. \& HARA, Y. 1995. Isolation and structural analysis of yacon oligosaccharides. Bioscience, Biotechnology \& Biochemistry 59: 2346-2347.

GUPTA, A.K., JAIN, H., KAUR, N. \& SINGH, R. 1993. Regulation of activity and properties of inulinases from roots of Cichorium intybus L. In Inulin and inulincontaining crops. (A. Fuchs, ed.). Elsevier Science Publishers. The Netherlands, p. 205-210.

HENSON, C.A. 2000. Enzymology of fructan polymerization and depolymerization in grasses. In Carbohydrate Reserves in Plants - Synthesis and Regulation (A.K. Gupta \& N. Kaur, eds.). Elsevier Science Publishers, Amsterdan, p. 269-281.

HENSON, C.A. \& LIVINGSTON, D.P.III. 1996. Purification and characterization of an oat fructan exohydrolase that preferentially hydrolyses b-2,1-fructans. Plant Physiology 110:639-644.

ISEJIMA, E.M. \& FIGUEIREDO-RIBEIRO, R.C.L. 1993. Dynamics of fructans in tuberous roots of Viguiera discolor Baker (Asteraceae) as influenced by phenology. Plant Cell Physiology 34:723-727.

ISEJIMA, E.M., FIGUEIREDO-RIBEIRO, R.C.L. \& ZAIDAN, L.B.P. 1991. Fructan composition in adventitious tuberous roots of Viguiera discolor Baker (Asteraceae) as influenced by daylength. New Phytologist 119:149-154.
ITAYA, N.M., BUCKERIDGE, M.S. \& FIGUEIREDO-RIBEIRO, R.C.L. 1997. Biosynthesis in vitro of high-molecularmass fructan by cell-free extracts from tuberous roots of Viguiera discolor (Asteraceae). New Phytologist 136:53-60.

ITAYA, N.M., FIGUEIREDO-RIBEIRO, R.C.L. \& BUCKERIDGE, M.S. 1999. Synthesis of fructans by fructosyltransferase from the tuberous roots of Viguiera discolor (Asteraceae). Brazilian Journal of Medical and Biological Research 32:435-442.

ITAYA, N.M., CARVALHO, M.A.M. \& FIGUEIREDORIBEIRO, R.C.L. 2002. Fructosyl trasferase and hydrolase activities in rhizophores and tuberous roots upon growth of Polymnia sonchifolia (Asteraceae). Physiologia Plantarum 116:451-459.

JERMYN, M. A. 1956. A new method for the determination of ketohexoses in presence of aldohexoses. Nature 177:38-39.

KANAYA, K.I., CHIBA, S. \& SHIMOMURA, T. 1978. Thin layer chromatography of linear oligosaccharides. Agricultural and Biological Chemistry 42:1947-1948.

KOOPS, A.J. \& JONKER, H.H. 1996. Purification and characterization of the enzymes of fructan biosynthesis in tubers of Helianthus tuberosus Colombia. II. Purification of Sucrose: sucrose 1-fructosyltransferase and reconstitution of fructan synthesis in vitro with purified Sucrose: sucrose 1-fructosyltransferase and Fructan:fructan 1-fructosyltrans-ferase. Plant Physiology 110:1167-1175.

LÜSCHER, M., ERDIN, C., SPRENGER, N.,HOCHSTRASSER, U., BOLLER, T. \& WIEMKEN, A. 1996. Inulin synthesis by a combination of purified fructosyl transferases from tubers of Helianthus tuberosus. FEBS Letter 385:39-42.

MARX, S.P., NÖSBERGER, J. \& FREHNER, M. 1997. Seasonal variation of fructan-b-fructosidase (FEH) activity and characterization of a $\beta-(2,1)$-linkage specific FEH from tubers of Jerusalem artichoke (Helianthus tuberosus). New Phytologist 135:267-277.

POLLOCK, C.J. 1986. Fructans and the metabolism of sucrose in vascular plants. New Phytologist 104:1-24.

POLLOCK, C.J. \& JONES, T. 1979. Seasonal patterns of fructan metabolism in forage grasses. New Phytologist 83:9-5.

SEGEL, I.H. 1979. Enzyme kinetics. John Wiley \& Sons, New York.

SHIOMI, N. 1993. Structure of fructo-polysaccharide (asparagosin) from roots of asparagus (Asparagus officinalis L.). New Phytologist 123:263-270.

SHIOMI, N., ONODERA, S., VIEIRA, C.C.J. \& FIGUEIREDO-RIBEIRO, R.C.L. 1996. Structure of fructan polymer from tuberous roots of of Gomphrena macrocephala St.-Hil., a herbaceous Amaranthaceae from the cerrado. New Phytologist 133:643-650. 
SOMOGYI, M. 1945. A new reagent for the determination of sugars. Journal of Biological Chemistry 160:61-63.

TERTULIANO, M.F. \& FIGUEIREDO-RIBEIRO, R.C.L. 1993. Distribution of fructose polymers in herbaceous species of Asteraceae from the cerrado. New Phytologist 123:741-749.

VANDENENDE, W. \& VANLAERE, A. 1996. De-novo synthesis of fructans from sucrose in vitro by a combination of two purified enzymes (sucrose: sucrose 1-fructosyl transferase and fructan: fructan 1-fructosyl transferase) from chicory roots (Cichorium intybus L.). Planta 200:335-342.

VANDEN ENDE, W., VAN WONTERGHEM, D., VERHAERT, P., DEWIL, E. \& VAN LAERE, A. 1996. Purification and characterization of fructan: fructan fructosyltransferase from chicory (Cichorium intybus L.) roots. Planta 199:493-502.
VAN DEN ENDE, W., MICHIELS, A., VAN WONTERGHEM, D., CLERENS, S.P., DE ROOVER, J. \& VAN LAERE, A.J. 2001. Defoliation induces fructan 1- exohydrolase II in witloof chicory roots. Cloning and purification of two isoforms, fructan 1-exohydrolase IIa and fructan 1-exohydrolase IIb. Mass fingerprint of the fructan 1-exohydrolase II enzymes. Plant Physiology 126:1186-1195.

WISE, C.S., DIMLER, R.J., DAVIS, H.A \& RIST, C.E. 1955. Determination of easily hydrolysable fructose units in dextran preparation. Analytical Chemistry 27:33-36.

YAMAMOTO, S. \& MINO, Y. 1985. Partial purification and properties of phleinase induced in stem base of orchargrass after defoliation. Plant Physiology 78:591-595. 